\title{
Hakikat Labelisasi Halal terhadap Perlindungan Konsumen di Indonesia
}

\author{
The Essences of Halal Labeling of the Consumer Protection \\ within Indonesia
}

\author{
Hijrah Lahaling', Kindom Makkulawuzar ${ }^{1}$, Singkeru Rukka ${ }^{2}$ \\ ${ }^{1}$ Fakultas Hukum, Universitas Ichsan Gorontalo \\ Jln. Raden Shaleh, Kota Gorontalo, Provinsi Gorontalo, 96115, Indonesia. \\ Tel./Fax:+62-435-829975 E-mail: ijhomakassar@yahoo.co.id \\ ${ }^{2}$ Program Pascasarjana Universitas Hasanuddin
}

Jln. Perintis Kemerdekaan. KM. 10, Tamalanrea, Sulawesi Selatan, 90245, Indonesia.

Tel./Fax: +62-411-585035 E-mail: singkeru@yahoo.co.id

Submitted: Jun 17, 2015; Reviewed: Jul 26, 2015; Accepted: Aug 3, 2015

\begin{abstract}
Halal labeling is not simply a means of meeting the bodily needs. Simultaneously, it serves to satisfy the spiritual needs. Both Halal and Haram foods are easy to identify when still in its fresh state. But as it underwent processing, it might be difficult to determine its Halal status. The objectives of this paper are to determine the aspects of legal protection available for the consumers to be able to conveniently trade any food product they desired, to illustrate the MUI Authority as the competent authority with sole power to issue a fatwa to decide halal or haram status offood products around Indonesia; and finally to identify the extent of control held by the Government, LPKSM, and society as the parties playing important roles in monitoring the products or goods on the market. The results showed that the legal protection for the consumers remains weak. Furthermore, there is no maximum supervision carried out by the government, LPKSM, or through society. The presence of JPH Law No. 33 of 2014 still incites polemic, one of which related to the monopoly of authority by MUI.
\end{abstract}

Keywords: Consumer Protection; Halal Labeling; Islamic Law; MUI

\begin{abstract}
Abstrak: Labelisasi halal tidak sekedar sarana pemenuhan kebutuhan lahiriah, tetapi sekaligus kebutuhan spiritual. Kehalalan dan keharaman makanan biasanya mudah diketahui bila dalam keadaan segar. Tetapi jika setelah mengalami proses pengolahan, maka akan sulit menentukan kehalalannya. Tujuan penulisan ini adalah untuk mengetahui aspek perlindungan hukum bagi konsumen untuk secara nyaman dapat melakukan transaksi terhadap produk makanan yang dikehendaki, untuk mengetahui Kewenangan MUI sebagai pihak yang berwenang dan memiliki otoritas mengeluarkan fatwa di Indonesia terkait kehalalan dan keharaman produk pangan; dan untuk mengetahui sejauhmana pengawasan yang dilakukan oleh Pemerintah, LPKSM, dan masyarakat sebagai pihak yang berperan penting dalam melakukan pengawasan terhadap produk atau barang yang beredar di pasaran. Hasil penelitian ini menunjukkan bahwa masih lemahnya perlindungan hukum bagi konsumen, tidak maksimalnya pengawasan yang dilakukan oleh pemerintah, LPKSM, dan masyarakat. Selain itu hadirnya UU JPH No. 33 Tahun 2014 masih menuai polemik salah satunya terkait monopoli kewenangan oleh MUI.
\end{abstract}

Kata kunci: Hukum Islam; Labelisasi Halal; MUI; Perlindungan Konsumen 


\section{PENDAHULUAN}

Pasal 1 angka 1 Undang-Undang Nomor 18 Tahun 2012 tentang Pangan mengatur bahwa pangan adalah segala sesuatu yang berasal dari sumber hayati produk pertanian, perkebunan, per-ikanan, peternakan, perairan, dan air, baik yang diolah maupun tidak diolah, yang diperuntukkan sebagai makanan atau minuman bagi konsumsi manusia, termasuk bahan tambahan Pangan, bahan baku Pangan, dan bahan lain yang digunakan dalam proses penyiapan, pengolahan, dan/atau pembuatan makanan atau minuman.

Pangan merupakan kebutuhan dasar manusia yang paling utama dan pemenuhannya merupakan bagian dari hak asasi setiap rakyat Indonesia. Pangan harus senantiasa tersedia secara cukup, aman, bermutu, bergizi, dan beragam dengan harga yang terjangkau oleh daya beli masyarakat, serta tidak bertentangan dengan agama, keyakinan, dan budaya masyarakat. ${ }^{1}$ Khususnya tentang keterangan halal untuk suatu produk pangan sangat penting bagi masyarakat Indonesia yang mayoritas beragama Islam, karena mengonsumsi makanan halal bagi umat muslim adalah sebuah kewajiban.

Muhammad Ibnu Elmi As Pelu, mengemukakan bahwa, Islam tidak membiarkan seseorang (konsumen) muslim untuk mengonsumsi pangan apa saja lantaran alasan survivalitas hidupnya, melainkan harus mengacu pada tujuan syari'ah. ${ }^{2}$ Sesuai

1 Hadi Setia Tunggal. "Perundang-Undangan Pangan Terbaru" dalam Sofyan Hasan. (2014). Sertifikasi Halal dalam Hukum Positif Regulasi dan Implementasi di Indonesia. Yogyakarta: Aswaja Pressindo, hlm. 1

2 Muhammad Elmi As Pelu. (2009). Label Halal: Antara Spiritualitas Bisnis dan Komoditas Agama. Malang: Madani, hlm. 2 dengan aturan yang telah ditetapkan di dalam Al-Qur'an dan sunnah Rasulullah.

Islam berada di antara suatu faham kebebasan soal makanan dan extrim dalam soal larangan. ${ }^{3}$ Oleh karena itu Islam kemudian mengumandangkan kepada segenap ummat manusia yang ditegaskan dalam al-Qur'an Surat Al-Baqarah (2) ayat 168:

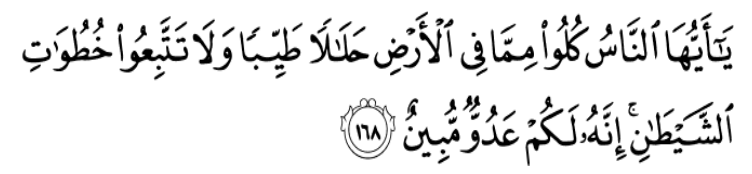

"Hai sekalian manusia, makanlah yang halal lagi baik dari apa yang terdapat di bumi, dan janganlah kamu mengikuti langkah-langkah syaitan; karena sesungguhnya syaitan itu adalah musuh yang nyata bagimu". ${ }^{4}$

Pangan halal dan thayyib (baik) merupakan hal yang ditetapkan dalam syari'at Islam $^{5}$ seperti ditegaskan dalam al-Qur'an Surat al-Maidah (5): 88:

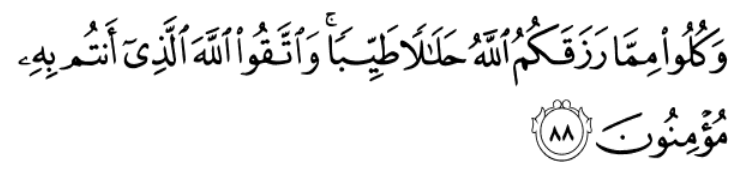

"Dan makanlah makanan yang halal lagi baik dari apa yang Allah Telah rezekikan kepadamu, dan bertakwalah kepada Allah yang kamu beriman kepada-Nya". ${ }^{6}$

Selanjutnya, Islam memberikan penjelasan mengenai persoalan-persoalan mana saja yang halal dan mana saja yang haram, seperti yang di atur dalam surat Al-Baqarah

Syekh Muh. Yusuf Qardhawi. (1980). Halal dan Haram Dalam Islam. Surabaya: PT. Bina Ilmu, hlm. 53

4 Departemen Agama Republik Indonesia. (1971). Al-Qur'an dan Terjemahnya. Jakarta: Yayasan Penyelenggara Penerjemah/Penafsir Al-Qur'an, hlm. 41

5 Sofyan Hasan. (2014). Sertifikasi Halal dalam Hukum Positif Regulasi dan Implementasi di Indonesia. Yogyakarta: Aswaja Pressindo, hlm. 17

6 Departemen Agama Republik Indonesia, Op.Cit., hlm. 176 
(2) ayat 173 , ayat tersebut menjelaskan secara tegas mengenai empat jenis makanan yang haram dikonsumsi, yaitu bangkai, darah, daging babi, dan binatang yang (ketika disembelih) disebut (nama) selain Allah. ${ }^{7}$ Di luar itu, hadis-hadis Nabi saw menambahkan beberapa jenis binatang yang haram dikonsumsi seperti binatang buas yang bertaring, berkuku tajam, binatang yang hidup di dua alam (darat dan laut), potongan dari binatang yang masih hidup, dan

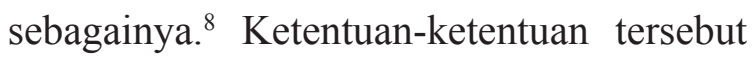
harus ditaati dan dipedomani oleh setiap muslim dalam mengonsumsi makanan.

Di samping itu, setiap makanan yang dikonsumsi dan masuk ke dalam tubuh sangat memengaruhi hubungan manusia dengan Tuhannya (hablum minallah). Makanan yang haram atau yang diperoleh secara haram akan menjadi penghalang diterimanya ibadah dan dikabulkannya do'a.

Pada zaman dahulu, seseorang akan dengan mudah mengetahui dan mengidentifikasi mana makanan yang halal dikonsumsi untuk memenuhi kebutuhan hidupnya dan mana makanan yang haram. Berbeda halnya dengan zaman sekarang ketika kemajuan ilmu pengetahuan dan teknologi (iptek) telah berkembang dengan pesatnya termasuk di dalamnya teknologi makanan. Setiap hari di hadapan masyarakat tersaji berbagai aneka jenis produk makanan olahan dan minuman aneka cita rasa. Semuanya itu dibuat dari berbagai macam bahan yang telah diolah dengan mesin berteknologi tinggi dan campuran bahan-bahan kimiawi sehingga sulit dikenali lagi asal usul bahan tersebut.

Ibid., hlm. 42

8 Sayyid Sabiq. (1983). Fiqih Sunnah. Jakarta: Pena Publishing, hlm 249.
Meskipun sudah dicantumkan komposisinya dalam setiap kemasannya, hal itu tetap saja sulit dipahami karena menggunakan istilahistilah ilmiah yang sulit dipahami oleh orang awam. ${ }^{9}$

Sementara itu, Indonesia yang telah memasuki era perdagangan bebas juga telah membuka keran impor lebar-lebar. Berbagai macam produk impor masuk ke Indonesia termasuk makanan olahan. Hal ini menjadi ancaman baik secara ekonomis maupun secara agamis. Secara ekonomis, kehadiran produk-produk tersebut menjadi saingan produk-produk lokal, sedangkan secara agamis kehadiran produk-produk tersebut semakin menambah daftar makanan yang disangsikan kehalalannya oleh umat Islam. Hal ini diperparah lagi oleh ketidakpedulian produsen makanan di Indonesia terhadap kehalalan makanan yang mereka hasilkan. ${ }^{10}$ Hal tersebut disebabkan karena mayoritas produsen makanan itu berasal dari kalangan non-muslimyang sulit diharapkan kepedulian dan komitmennya terhadap makanan halal.

Sebagaimana dikutip dalam Sopa ${ }^{11}$, kondisi tersebut kemudian diperparah lagi oleh produsen muslim sendiri yang kurang peduli yang diakibatkan oleh rendahnya kadar keimanan mereka sehingga motif bisnis lebih dominan daripada tanggung jawab menyelamatkan konsumen yang mayoritas

9 Dirjen Bimas Islam dan Penyelenggaraan Haji. (2003). Bagian Proyek Sarana dan Prasarana Produk Halal. Jakarta: Departemen Agama RI, hlm: 242-288

10 Lihat pernyataan Alim Wardoyo anggota Tim Pakar draft RUU Jaminan Produk Halal. (2006). Pikiran Rakyat. edisi 1 Agustus.

11 Sopa. (2013). Sertifikasi Halal Majelis Ulama Indonesia (Studi atas Fatwa Halal MUI terhadap Produk Makanan, Obat-Obatan dan Kosmetika. Jakarta: GP Press Group, hlm. 4 
muslim dari konsumsi makanan yang haram. Kalaupun ada yang peduli, ternyata partisipasi mereka dalam memproduksi makanan yang halal masih jauh dari yang diharapkan sebagai akibat dari rendahnya pengetahuan agama mereka terutama dalam masalah halal dan haramnya makanan. Hal tersebut sangat bertentangan dengan Undang-Undang Nomor 8 Tahun 1999 tentang Perlindungan Konsumen yang juga mengatur terkait persoalan halal. Persoalan tersebut berkaitan erat dengan hak dan kewajiban konsumen dan produsen atau yang disebut sebagai pelaku usaha.

Pasal 4 huruf (a) dan (c), mengatur bahwa hak konsumen adalah hak atas kenyamanan, keamanan, dan keselamatan dalam mengkonsumsi barang dan/atau jasa. Hak atas informasi yang benar, jelas, dan jujur mengenai kondisi dan jaminan barang dan/ atau jasa. Bersamaan dengan itu, dalam Pasal 7 huruf (a) dan (b) bahwa kewajiban pelaku usaha adalah beritikad baik dalam melakukan kegiatan usahanya dan memberikan informasi yang benar, jelas dan jujur mengenai kondisi dan jaminan barang dan/ atau jasa. Dalam Pasal 8 ayat (1) huruf (h), pelaku usaha dilarang memroduksi dan/ atau memerdagangkan barang dan/atau jasa yang tidak mengikuti ketentuan berproduksi secara halal, sebagaimana pernyataan "halal" yang dicantumkan dalam label. ${ }^{12}$

Ketentuan mengenai perlindungan konsumen tersebut sebenarnya telah tercantum dalam pembukaan UUD NRI 1945 alinea IV yang menegaskan komitmen Indonesia untuk melindungi segenap bangsa

12 Undang-Undang Nomor 8 Tahun 1999 tentang Perlindungan Konsumen.. dan seluruh tumpah darah Indonesia. ${ }^{13}$ Hadirnya Undang-Undang Nomor 33 Tahun 2014 tentang Jaminan Produk Halal (UUJPH) telah merepresentasikan tanggung jawab negara, khususnya terhadap umat Islam, untuk melindungi dan memberikan rasa tenang dan aman dalam mengonsumsi/ menggunakan produk yang sesuai syari'at yakni halal dan thayyib. Selain itu, juga menumbuhkan kesadaran tentang pentingnya produk halal dan mewajibkan produsen untuk memberikan jaminan kehalalan produk. Produk yang dimaksud adalah makanan, minuman, kosmetik dan lain-lain. UU JPH setidaknya menjadi landasan hukum tentang sistem informasi produk halal sebagai pedoman pelaku usaha dan masyarakat.

Namun pada tataran praksis, UU Jaminan Produk Halal menuai polemik setelah Majelis Ulama Indonesia (MUI) dianggap memonopoli penetapan halal dan haram sebuah produk. Mereka diduga menggunakan kewenangan tersebut untuk mendapat «jatah» dari pelaku usaha. Monopoli fatwa ini pun cenderung menyeret oknum di dalamnya bersikap tidak independen, cenderung koruptif, elitis, dan intimidatif. Mereka akan mudah tergoda oleh banyaknya uang yang digelontorkan pengusaha demi mendapatkan sertifikat dan labelisasi halal. Diantaranya adalah munculnya pemberitaan tentang Majelis Ulama Indonesia menerima fee dari bisnis sertifikasi label halal oleh Islamic Food and Nutrition of America (IFANCA) di Chicago, Amerika Serikat. Besarnya komisi itu mencapai 40 persen dari setiap label yang dikeluarkan IFANCA untuk perusahaan makanan dan minuman di

13 Lihat Pembukaan Undang-Undang Dasar 1945. 
benua tersebut. ${ }^{14}$

Berdasarkan uraian tersebut di atas, maka rumusan masalah pada tulisan ini sebagai berikut: Pertama, Aspek perlindungan hukum terhadap konsumen di Indonesia; Kedua, Pengawasan terhadap produk labelisasi Halal di Indonesia; Ketiga, Kewenangan MUI sebagai lembaga yang memiliki otoritas terhadap legalitas kehalalan.

\section{METODE}

Adapun tipe penelitian yang digunakan adalah penelitian hukum normatif (normative legal research). ${ }^{15}$ Penelitian ini bertumpu pada studi kepustakaan (library research) dengan menggunakan pendekatan undangundang (statute approach), dan pendekatan konseptual (conceptual approach). ${ }^{16}$

\section{ANALISIS DAN PEMBAHASAN}

\section{Aspek Perlindungan Hukum terhadap}

\section{Konsumen di Indonesia}

Indonesia sebagai negara berkembang, yang industrinya baru mengalami tahap permulaan, perkembangan hukum perlindungan konsumennya belum berkembang sebagaimana di negara-negara maju. Hal ini disebabkan oleh lazimnya perkembangan perlindungan konsumen merupakan akibat dari perkembangan industri suatu negara, yaitu industrialisasi massal. ${ }^{17}$

14 Dikutip pada laman website: nasional.tempo.col read/news/2014/08/05/173597253/mui-terimafee-label-halal-dari-chicago [Diakses pada tanggal 31 Mei 2015].

15 Zainuddin Ali. (2011). Metode Penelitian Hukum. Ed. 1 Cet.3. Jakarta: Sinar Grafika, hlm. 24-25

16 Peter Mahmud Marzuki. (2013). Penelitian Hukum. Cetakan Kedelapan. Jakarta: Kencana, hlm. 133

17 Ahmadi Miru. (2013). Prinsip-Prinsip Perlindungan Hukum Bagi Konsumen di Indonesia. Jakar-
Konsumen adalah setiap orang pemakai barang dan/atau jasa yang tersedia dalam masyarakat, baik bagi kepentingan diri sendiri, keluarga, orang lain maupun makhluk hidup lain dan tidak untuk diperdagangkan. ${ }^{18}$ Karena posisi konsumen yang lemah maka ia harus dilindungi oleh hukum. Salah satu sifat, sekaligus tujuan hukum itu adalah memberikan perlindungan (pengayoman) kepada masyarakat. ${ }^{19}$

Pemberdayaan konsumen dapat dilakukan melalui penerapan hukum perlindungan konsumen yang memadai, di mana hukum perlindungan konsumen ini menjadi relevan pada tiga tahap transaksi konsumen, yaitu prapembelian, saat pembelian, dan purna pembelian. ${ }^{20}$ Pemberdayaan konsumen ini harus diakui bahwa bukan pekerjaan yang mudah, namun harus tetap diusahakan agar kondisinya tidak semakin buruk, bahkan diusahakan dapat berimbang dengan posisi produsen yang selama ini jauh lebih unggul daripada konsumen. ${ }^{21}$

Pasal 1 angka 1 UU No. 8 Tahun 1999 tentang Perlindungan Konsumen memberi pengertian perlindu-ngan konsumen sebagai segala upaya yang menjamin adanya kepastian hukum untuk memberi perlindungan kepada konsumen. Dalam usaha memberikan perlindungan hukum terhadap konsumen terdapat beberapa asas yang terkandung di dalamnya. Asas tersebut adalah:

1. Asas Manfaat; asas ini dimaksudkan untuk mengamanatkan bahwa segala

ta: PT. RajaGrafindo Persada, hlm. 67.

18 Lihat Pasal 1 angka 2 UU No. 8 Tahun 1999.

19 Shidarta. (2000). Hukum Perlindungan Konsumen Indonesia. Jakarta: Grasindo, hlm. 9

20 Gerald J. Thain. "Consumer law Its Development and Present State in the USA" dalam Ahmadi Miru. (2013). Op. Cit., hlm. 41

21 Ahmadi Miru. Loc.cit. 
upaya dalam penyelenggaraan perlindungan konsumen harus memberikan manfaat sebesar-besarnya bagi kepentingan konsumen dan pelaku usaha secara kese-luruhan. Asas ini diharapkan bahwa pengaturan dan penegakan hukum perlindungan konsumen bermanfaat bagi seluruh lapisan masyarakat dan pada gilirannya bermanfaat bagi kehidupan berbangsa.

2. Asas Keadilan; asas ini dimaksudkan agar partisipasi seluruh rakyat dapat diwujudkan secara maksimal dan memberikan kesempatan kepada konsumen dan pelaku usaha untuk memperoleh haknya dan melaksanakan kewajibannya secara adil. Karena itu UUPK mengatur sejumlah hak dan kewajiban konsumen dan pelaku usaha.

3. Asas Keseimbangan; asas ini dimaksudkan untuk memberikan keseimbangan antara kepentingan konsumen, pelaku usaha, dan pemerintah dalam arti materiil ataupun spiritual. Tidak ada salah satu pihak yang mendapat perlindungan atas kepentingannya yang lebih besar dari pihak lain sebagai komponen bangsa dan Negara.

4. Asas Keamanan dan Keselamatan konsumen; asas ini dimaksudkan untuk memberikan jaminan atas keamanan dan keselamatan kepada konsumen dalam penggunaan, pemakaian dan pemanfaatan barang dan/atau jasa yang dikonsumsi atau digunakan. Oleh karena itu, UUPK ini membebankan sejumlah kewajiban yang harus dipenuhi dan menetapkan sejumlah larangan yang harus dipatuhi oleh produsen dalam memproduksi dan mengedarkan produknya.

5. Asas Kepastian Hukum; asas ini dimaksudkan agar baik pelaku usaha maupun konsumen menaati hukum dan memperoleh keadilan dalam penyelenggaraan perlindungan konsumen, serta Negara menjamin kepastian $\mathrm{Hu}-$ kum. ${ }^{22}$

Memerhatikan substansi Pasal 2 UUPK beserta penjelasannya, tampak bahwa perumusannya mengacu pada filosofi pembangunan nasional yaitu pembangunan manusia Indonesia seutuhnya yang berlandaskan pada Falsafah Negara Republik Indonesia. Kelima asas yang disebutkan dalam Pasal tersebut, dapat digolongkan menjadi 3 (tiga) asas, yaitu: Pertama, Asas Kemanfaatan yang di dalamnya meliputi asas keamanan dan keselamatan konsumen; Kedua, Asas Keadilan, yang di dalamnya meliputi asas keseimbangan; dan Ketiga, Asas Kepastian Hukum. ${ }^{23}$

Sejalan dengan pendapat Sudikno Mertokusumo, ${ }^{24}$ hukum harus dilaksanakan

22 Anak Agung Ayu Diah Indrawati. (2011). Perlindungan Hukum Konsumen dalam Pelabelan Produk Pangan. Available from: unud-376-95861053-final tesis.pdf. hlm.65-66 [Diakses pada tanggal 25 September 2014]

23 Ibid

24 Hukum berfungsi sebagai perlindungan kepentingan manusia. Agar kepentingan manusia terlindungi, hukum harus dilaksanakan. Pelaksanaan hukum dapat berlangsung secara normal, damai, tetapi dapat terjadi juga karena pelanggaran hukum. Dalam hal ini hukum yang telah dilanggar itu harus ditegakkan. Melalui penegakan hukum inilah hukum itu menjadi kenyataan. Dalam menegakkan hukum ada tiga unsur yang selalu harus diperhatikan, yaitu: Kepastian Hukum (Rechtssichherheit), Kemanfaatan (Zweckmassigkeit) dan Keadilan (Gerechtigkeit). Lihat Sudikno Mertokusumo. (1986). Mengenal Hukum (suatu pengantar). Yogyakarta: Liberty, hlm. 130 
dan ditegakkan; fiat justitia et pereat mun$d u s$ (meskipun dunia ini runtuh hukum harus ditegakkan) itulah yang diinginkan oleh kepastian hukum. Sebaliknya masyarakat mengharapkan pelaksanaan hukum atau penegakan hukum harus memberi manfaat atau kegunaan dan memperhatikan keadilan, bukan justru menimbulkan keresahan di dalam masyarakat. ${ }^{25}$

Walaupun hukum yang berkuasa, tetapi bukan berarti bahwa hukum itu diciptakan tanpa memperhatikan anasir-anasir di luar hukum, utamanya moralitas. Hukum adalah perlindungan kepentingan manusia, hukum adalah kepentingan manusia, sehingga rule of law tidak boleh diartikan bahwa manusia pasif dan menjadi budak hukum. Hukum dibentuk dengan dasar moral mampu memprediksi gejala sosial yang akan ditimbulkan, hukum dikatakan pula merupakan produk yang mutakhir yang mampu mengikuti perkembangan zaman. ${ }^{26}$

Adapun tujuan perlindungan konsumen, sebagaimana termaksud dalam ketentuan Pasal 3 UUPK bertujuan:

1. Meningkatkan kesadaran, kemampuan, dan kemandirian konsumen untuk melindungi diri;

2. Mengangkat harkat dan martabat konsumen dengan cara menghindarkannya dari ekses negatif pemakaian barang dan/atau jasa;

3. Meningkatkan pemberdayaan konsumen dalam memilih, menentukan dan menuntut hak-haknya sebagai kon-

25 Sudikno Mertokusumo. Ibid. hlm. 130-131

26 Mustofa Bola, dkk. (2015). "Korelasi Putusan Hakim Tingkat Pertama, Tingkat Banding, dan Tingkat Kasasi (Suatu Studi tentang Aliran Pemikiran Hukum)" Jurnal Hasanuddin Law Review (HALREV), 1(1): 37 sumen;

4. Menciptakan sistem perlindungan konsumen yang megandung unsur kepastian hukum dan keterbukaan informasi serta akses untuk mendapatkan informasi;

5. Menumbuhkan kesadaran pelaku usaha mengenai pentingnya perlindungan konsumen sehingga tumbuh sikap yang jujur dan bertanggungjawab dalam berusaha

6. Meningkatkan kualitas barang dan/ atau jasa yang menjamin kelangsungan usaha produksi barang dan/atau jasa, kesehatan, kenyamanan, keamanan, dan keselamatan konsumen.

Teori perlindungan yang dikemukakan oleh Philipus M. Hadjon, ${ }^{27}$ menyebutkan bahwa perlindungan hukum terbagi atas dua, yaitu perlindungan hukum represif dan perlindungan hukum preventif. Perlindungan hukum represif yaitu perlindungan hukum yang dilakukan dengan cara menerapkan sanksi terhadap pelaku agar dapat memulihkan hukum kepada keadaan sebenarnya. Perlindungan jenis ini biasanya dilakukan di Pengadilan. Perlindungan hukum preventif yaitu perlindungan hukum yang bertujuan

27 Lihat lebih lanjut Ridwan, HR. "Hukum Administrasi Negara" dalam Yunus Wahid, dkk. (2015). "Penegakan Hukum Lingkungan di Sektor Kehutanan (Studi Kawasan Hutan Lindung di Kabupaten Sinjai, Sulawesi Selatan)" Jurnal Hasanuddin Law Review (HARLEV), 1(1): 66. Teori Sanksi menurut Philipus M. Hadjon, bahwa penerapan sanksi secara bersama-sama antara hukum administrasi dan hukum lainnya dapat terjadi, yakni kumulasi internal dan kumulasi eksternal. Kumulasi eksternal merupakan penerapan sanksi administrasi bersama-sama dengan sanksi lain seperti sanksi pidana atau sanksi perdata. Adapun kumulasi internal merupakan penerapan dua atau lebih sanksi administrasi secara bersama-sama, misalnya pencabutan izin dan pengenaan denda. 
untuk mencegah terjadinya suatu sengketa. Perlindungan hukum jenis ini misalnya sebelum Pemerintah menetapkan suatu aturan/ keputusan, rakyat dapat mengajukan keberatan atau dimintai pendapatnya mengenai rencana keputusan tersebut. ${ }^{28}$

Dengan demikian, agar tujuan hukum perlindungan konsumen ini dapat berjalan sebagaimana yang dicita-citakan, hal ini harus diperkuat oleh kesatuan dari keseluruhan sub sistem yang terkandung dalam undangundang perlindungan konsumen didukung oleh sarana dan fasilitas yang menunjang.

\section{Pengawasan Terhadap Labelisasi Halal di Indonesia}

Islam sebagai agama yang senantiasa terikat pada ketentuan syari'ah, memiliki pengaturan yang jelas terkait pelaksanaan syariat dalam kehidupan sehari-hari, termasuk dalam aspek pangan. Salah satu wujud perlindungan dalam aspek pangan tersebut adalah dalam bentuk pencantuman label halal dalam produk pangan kemasan yang dijual di pasaran, sehingga dengan demikian maka pihak konsumen dapat mengetahui secara pasti perihal kondisi dari produk pangan yang akan dikonsumsinya tersebut.

Perkembangan pengaturan Jaminan Produk Halal pada dasarnya akan senantiasa sejalan dengan perkembangan pengaturan labelisasi pada produk pangan, karena melalui aspek labelisasi tersebutlah konsumen dapat mengetahui kondisi halal atau tidaknya suatu

28 Philipus M. Hadjon. "Perlindungan Hukum Bagi Rakyat di Indonesia" dalam Anak Agung Ayu Diah Indrawati. (2011). Perlindungan Hukum Konsumen dalam Pelabelan Produk Pangan. Available from: unud-376-95861053-final tesis. pdf, hlm. 41 [Diakses pada tanggal 25 September 2014] produk yang akan dibeli dan dikonsumsinya.

Label merupakan penanda dan sumbersumber informasi tentang substansi yang diwakilinya. Karena itu isi label haruslah sesuatu yang benar dan harus dapat dipertanggungjawabkan. Dalam pandangan konsumen, label menjadi sangat penting karena bagi konsumen label dapat memberikan tiga hal pokok, yakni:

1. Informasi yang dibutuhkan sebagai pertimbangan untuk membeli atau tidak membeli suatu produk tertentu.

2. Dengan pengetahuan tersebut, konsumen dapat menentukan, memilih satu produk atas produk sejenis lainnya.

3. Dengan informasi yang benar dan lengkap, konsumen juga dapat terhindar dari kemungkinan gangguan keamanan dan keselamatan konsumsinya, bila produksi yang bersangkutan tidak cocok untuk dirinya atau mengandung suatu zat yang membahayakan.

Perihal apa yang semestinya dicantumkan dalam label pangan, ketentuan UU Pangan No. 18 Tahun 2012 Pasal 97 ayat (3), mengatur bahwa label sekurang-kurangnya memuat:

1. Nama produk;

2. Daftar bahan yang digunakan;

3. Berat bersih atau isi bersih;

4. Nama dan alamat pihak yang memproduksi atau mengimpor;

5. Halal bagi yang dipersyaratkan;

6. Tanggal dan kode produksi

7. Tanggal, bulan, dan tahun kadaluwarsa.

8. Nomor izin edar bagi pangan olahan; dan

9. Asal usul bahan Pangan tertentu. 
Pasal 97 ayat (3) UU Pangan di atas, mengatur ketentuan tentang dimuatnya "keterangan tentang halal" dalam label setiap produk yang dijual di wilayah Indonesia. Ini menunjukkan bahwa keterangan halal untuk suatu produk pangan sangat penting bagi masyarakat Indonesia yang mayoritas memeluk agama Islam.

Namun dalam kenyataannya, seringkali pihak produsen mencantumkan label halal pada produk yang mereka jual, namun tidak sesuai dengan kondisi barang yang sebenarnya ataupun pencantuman tersebut tidak sesuai dengan ketentuan yang berlaku. Pada dasarnya prilaku produsen tersebut telah melanggar hak konsumen dan ketentuan syarat administratif yang ada. Oleh karena itu demi menegakkan dan menjamin hak-hak konsumen, maka diperlukan adanya pengawasan terhadap produk yang beredar di pasaran.

Pengawasan secara umum diartikan sebagai suatu kegiatan yang ditujukan untuk mengadakan evaluasi terhadap kegiatan yang akan atau yang telah dilakukan. Pengawasan dapat bersifat preventif dan represif. Pengawasan preventif adalah pengawasan sebelum suatu tindakan dalam pelaksanaan kegiatan, yang biasanya berbentuk prosedur yang harus ditempuh dalam pelaksanaan kegiatan tersebut, sedangkan pengawasan represif adalah pengawasan yang dilakukan setelah suatu tindakan dilakukan dengan membandingkan apa yang telah terjadi dengan apa yang seharusnya, dan diwujudkan dalam bentuk pemeriksaan setempat, verifikasi, monitoring dan sebagainya. ${ }^{29}$

29 Yunus Wahid, dkk. (2015). "Penegakan Hukum Lingkungan di Sektor Kehutanan (Studi Kawasan Hutan Lindung di Kabupaten Sinjai, Sulawesi Selatan)" Hasanuddin Law Review, 1(1): 65
Menurut George R. Terry, pengawasan adalah mendeterminasi apa yang telah dilaksanakan, maksudnya mengevaluasi prestasi kerja dan apabila perlu menerapan tindakantindakan korektif hasil pekerjaan apakah sesuai dengan rencana-rencana. Arifin Abdurachman menyatakan bahwa pengawasan adalah kegiatan/proses kegiatan untuk mengetahui hasil pelaksanaan, kesalahan, kegagalan untuk diperbaiki kemudian, dan mencegah terulangnya kembali kesalahankesalahan itu, begitu pula mencegah sehingga pelaksanaan tidak berbeda dengan rencana yang telah ditetapkan. ${ }^{30}$

Ketentuan perihal pengawasan terhadap produk pangan yang beredar, dapat ditemukan dalam beberapa peraturan perundang-undangan yang berkaitan dengan labelisasi dan produk pangan. Namun demikian, berkaitan dengan kedudukan UUPK sebagai perekat dari beberapa ketentuan peraturan perundang-undangan tersebut, maka dalam hal ini akan dikemukakan perihal pengawasan sebagaimana yang di maksud dalam ketentuan UUPK. Ketentuan Pasal 30 UUPK menentukan bahwa:

1. Pengawasan terhadap penyelenggaraan perlindungan konsumen serta penerapan ketentuan peraturan perundang-undangan diselenggarakan oleh pemerintah, masyarakat, dan lembaga perlindungan konsumen swadaya masyarakat.

2. Pengawasan oleh pemerintah sebagaimana dimaksud pada ayat (1) dilaksanakan oleh Menteri dan/atau Menteri teknis terkait.

$30 \quad$ Ibid 
3. Pengawasan oleh masyarakat dan lembaga perlindungan konsumen swadaya masyarakat dilakukan terhadap barang dan/atau jasa yang beredar di pasar.

4. Apabila hasil pengawasan sebagaimana dimaksud pada ayat (3) ternyata menyimpang dari peraturan perundangundangan yang berlaku dan membahayakan konsumen, Menteri dan/atau menteri teknis mengambil tindakan sesuai dengan peraturan perundangundangan yang berlaku.

5. Hasil pengawasan yang diselenggarakan masyarakat dan lembaga perlindungan konsumen swadaya masyarakat dapat disebarluaskan kepada masyarakat dan dapat disampaikan kepada menteri dan menteri teknis.

6. Ketentuan pelaksanaan tugas pengawasan, sebagaimana dimaksud pada ayat (1), ayat (2), dan ayat (3) ditetapkan dengan Peraturan Pemerintah.

Berdasarkan uraian ketentuan tersebut di atas, dapat dilihat bahwa pada dasarnya pengawasan dapat dilakukan oleh pemerintah maupun oleh LPKSM dan masyarakat. Dalam melaksanakan pengawasan, pihak pemerintah dalam hal ini berwenang untuk melakukan pengawasan tersebut sejak proses produksi, penawaran, promosi, pengiklanan, dan cara menjual sampai barang dan/ atau jasa tersebut beredar di pasaran.

Sementara kewenangan yang dimiliki oleh masyarakat dan LPKSM dalam melaksanakan pengawasan adalah berupa pengawasan terhadap barang dan jasa yang sudah beredar di pasar, yang dalam hal ini berarti mengindikasikan bahwa kewenangan pengawasannya tidak seluas pengawasan yang dilakukan oleh pihak pemerintah.

\section{Kewenangan Majelis Ulama Indonesia sebagai Lembaga yang memiliki Otoritas terhadap Legalitas Kehalalan}

Menurut Herbert G. Hick, ${ }^{31}$ wewenang atau otoritas adalah hak untuk melakukan sesuatu hal, dan itu merupakan kekuasaan yang sah. Dalam suatu organisasi otoritas merupakan hak yang dimiliki oleh seseorang untuk mengeluarkan instruksi terhadap orang lain dan untuk mengawasi bahwa semua akan ditaati.

Dalam pandangan Philipus M. Hadjon, wewenang (bevoegdheid) dideskripsikan sebagai kekuasaan hukum (rechtsmacht). Jadi dalam konsep hukum publik, wewenang berkaitan dengan kekuasaan. Setiap tindakan pemerintahan dan/atau pejabat umum harus bertumpu pada kewenangan yang sah. Kewenangan itu diperoleh melalui 3 sumber: Atribusi, pelimpahan (delegasi) dan Mandat. Kewenangan atribusi lazimnya digariskan melalui pembagian kekuasaan negara oleh undang-undang dasar, sedangkan kewenangan delegasi dan mandat adalah kewenangan yang berasal dari pelimpahan. ${ }^{32}$

MUI merupakan sebuah wadah yang di dalamnya terhimpun para ulama, $z u^{\prime} a m a^{33}$ dan cendekiawan muslim Indonesia. Berasaskan Islam dan bertujuan mewujudkan masyarakat yang berkualitas (khaira um-

31 Jum Anggriani. (2012). Hukum Administrasi Negara. Yogyakarta: Graha Ilmu, hlm. 87

32 Sebagaimana dikutip pada laman website; $\mathrm{https://}$ boeyberusahasabar.wordpress.com/2013/12/10/ sumber-kewenangan-atribusi-delegasi-danmandat/ [Diakses pada tanggal 17 Juni 2015]

33 Berasal dari bahasa Arab Nomina (kata benda) pemimpin (organisasi, pemerintahan, dan sebagainya). Sumver: Kamus Besar Bahasa Indonesia. (http://kamusbahasaindonesia.org/) 
mah), dan negara yang aman, damai, adil dan makmur rohaniah dan jasmaniah yang diridhai Allah SWT (baldatun thayyibatun wa rabbun ghafur). ${ }^{34}$

Kedudukan MUI terhadap produk halal adalah sentral dan sangat penting, oleh karena keberadaan MUI dalam kancah keormasan di tanah air ini diposisikan sebagai induk organisasi keislaman. Dinamika MUI dalam melayani kepentingan umat Islam di Indonesia ini ditunjang dengan dibentuknya beberapa komisi, antara lain Komisi Fatwa dan LPPOM MUI (Lembaga Pengkajian Pangan, Obat-obatan dan Kosmetika Majelis Ulama Indonesia) sebagai lembaga yang menangani khusus hukum pangan, obat-obatan dan kosmetika. ${ }^{35}$

Mengingat bahwa pada umumnya fatwa MUI itu dijadikan pedoman oleh pemerintah, maka satu hal yang disadari bersama ialah bahwa dalam soal kemasyarakatan, pemerintah diberi hak oleh hukum Islam untuk memilih satu pendapat yang paling membawa kemaslahatan dan memberlakukannya kepada seluruh umat, karena mazhab pemerintah adalah kemaslahatan. Apa yang telah ditetapkan oleh pemerintah ini mengikat bagi umat Islam yang ada di wilayah pemerintahannya dan umat Islam wajib mematuhinya. ${ }^{36}$

Dengan demikian, fatwa tidak boleh dikeluarkan oleh sembarangan pihak. Fatwa harus dikeluarkan oleh pihak atau lembaga

34 Lihat Pasal 5 Pedoman Dasar Majelis Ulama Indonesia

35 Bagian Proyek Sarana dan Prasarana Produk Halal Direktorat Jenderal Bimbingan Masyarakat Islam dan Penyelenggaraan Haji, Departemen Agama RI, 2003, Himpunan Fatwa Majelis Ulama Indonesia, hlm.x.

36 Ibid., hlm. xi. yang mempunyai kompetensi untuk itu. Jika fatwa dikeluarkan secara sembarangan akan melahirkan tindakan tahakkum (perbuatan membuat-buat hukum) dan tasyaru' (membuat-buat syari'at baru). Lembaga fatwa bersifat independen yang terdiri dari para ahli ilmu dan merupakan kelompok yang berkompeten dan memiliki otoritas yang memadai untuk memberikan keputusan-keputusan ilmiah. Lembaga ini dengan seluruh anggotanya selalu berpegang pada sumber pokok Islam (Qur'an dan Sunnah) dengan memerhatikan pendapat para ulama terdahulu.

Proses penetapan fatwa tentang produk makanan dan minuman halal pada prinsipnya sama dengan penetapan fatwa pada umumnya. Perbedaan terletak pada proses rapat penetapan fatwa dilakukan bersama antara komisi fatwa dengan lembaga pemeriksa yang dalam hal ini LPPOM MUI.

LPPOM MUI didasarkan atas dasar keputusan Majelis Ulama Indonesia Nomor: 018/MUI/1989 tanggal 6 Januari 1989 M/26 Jumadil Awal 1409 H. Adapun tugas-tugasnya sebagai berikut:

1. Mengadakan inventarisasi, klasifikasi, dan pengkajian terhadap kehalalan makanan, obat-obatan dan kosmetika yang beredar di masyarakat.

2. Mengkaji dan menyusun konsepkonsep yang berkaitan dengan upaya memproduksi dan memperjualbelikan suatu produk, penggunaan makanan, minuman serta obat-obatan yang sesuai dengan ajaran Islam.

3. Mengkaji dan menyusun konsep-konsep yang berkaitan dengan peraturanperaturan mengenai penyelenggaraan 
rumah makan/restoran, perhotelan, hidangan dalam pelayaran atau penerbangan, pemotongan hewan serta penggunaan berbagai jenis bahan bagi pengolahan pangan, obat-obatan dan kosmetika yang dipergunakan oleh masyarakat, khususnya umat Islam harus terjamin kehalalannya.

4. Menyampaikan hasil-hasil kajian dan konsep-konsep itu kepada Dewan Pimpinan MUI sebagai bahan pertimbangan dalam merumuskan kebijakan yang berkaitan dengan pengolahan, jual-beli dan penggunaan pangan, obatobatan dan kosmetika

5. Mengadakan berbagai kegiatan dalam rangka menjalin kerjasama dengan instansi-instansi pemerintah dan swasta, dalam dan luar Negeri.

Untuk memaksimalkan tugas dan fungsi LPPOM MUI dalam menjawab tuntutan masyarakat terhadap kebutuhan jaminan halal suatu produk, maka dilakukan penataan dan penyempurnaan baik internal maupun eksternal. Secara internal, berdasarkan SK MUI Nomor 330/MUI/IV/1991 dan SK Nomor 414/MUI/VIII/1998, dilakukan penyempurnaan redaksional mengenai tugas LPPOM MUI walaupun substansinya masih sama. Secara eksternal, LPPOM MUI membangun kemitraan dengan berbagai Departemen, Kementerian, Dinas/Instansi dan Lembaga Sertifikasi halal di luar negeri. ${ }^{37}$

\section{PENUTUP}

Ditinjau dari perspektif hukum Islam, pengaturan terkait pangan dengan jelas tidak membiarkan konsumen mengonsumsi pangan

37 Sofyan Hasan,. (2014). Op. Cit, hlm. 189. apa saja lantaran survivalitas hidup, melainkan harus mengacu pada aturan yang sudah ditetapkan dalam Al-Qur'an dan sunnah Rasulullah. Oleh karena posisi konsumen yang lemah, maka ia harus dilindungi oleh hukum. Di dalam usaha memberikan perlindungan hukum terhadap konsumen terdapat beberapa asas yang terkandung didalamnya, diantaranya adalah: asas kemanfaatan, asas keadilan, dan asas kepastian hukum.

Untuk menegakkan dan menjamin hak-hak konsumen, maka diperlukan adanya pegawasan terhadap produk yang beredar di pasaran. Pada dasarnya, pengawasan dapat dilakukan oleh pemerintah maupun oleh LPKSM dan masyarakat. Selain itu, Majelis Ulama Indonesia sebagai pihak yang berwenang dan memiliki otoritas mengeluarkan fatwa di Indonesia terkait kehalalan dan keharaman produk pangan, seharusnya lebih serius menangani persoalan halal dan haramnya produk yang beredar di pasaran.

\section{BIBLIOGRAFI}

A. M. Yunus Wahid, Naswar Bohari, dan Achmad. (2015). "Penegakan Hukum Lingkungan di Sektor Kehutanan (Studi Kawasan Hutan Lindung di Kabupaten Sinjai, Sulawesi Selatan)" Hasanuddin Law Review, 1(1): 61-73.

Ahmadi Miru. (2013). Prinsip-Prinsip Perlindungan Hukum Bagi Konsumen di Indonesia. Jakarta: PT. RajaGrafindo Persada.

AnakAgung Ayu Diah Indrawati. (2011).Perlindungan Hukum Konsumen dalam Pelabelan Produk Pangan. Available online at: unud-376-95861053-final tesis.pdf. (Diakses pada 25 September 2014). 
Dirjen Bimas Islam dan Penyelenggaraan Haji. (2003). Bagian Proyek Sarana dan Prasarana Produk Halal. Jakarta: Departemen Agama RI.

Jum Anggriani. (2012). Hukum Administrasi Negara. Yogyakarta: Graha Ilmu.

Muhammad Elmi As Pelu. (2009). Label Halal: Antara Spiritualitas Bisnis dan Komoditas Agama. Malang: Madani.

Mustofa Bola, Romi Librayanto, dan Muhammad Ilham Arisaputra. (2015). "Korelasi Putusan Hakim Tingkat Pertama, Tingkat Banding, dan Tingkat Kasasi (Suatu Studi tentang Aliran Pemikiran Hukum)" Hasanuddin Law Review, 1(1): 27-46.

Peter Mahmud Marzuki. (2013). Penelitian Hukum. Cetakan Kedelapan. Jakarta: Kencana.

Sayyid Sabiq. (1983). Fiqih Sunnah. Jakarta: Pena Publishing.

Shidarta. (2000). Hukum Perlindungan Konsumen Indonesia. Jakarta: Grasindo.

Sofyan Hasan. (2014). Sertifikasi Halal dalam Hukum Positif Regulasi dan
Implementasi di Indonesia. Yogyakarta: Aswaja Pressindo.

Sofyan Hasan. (2014). Sertifikasi Halal dalam Hukum Positif Regulasi dan Implementasi di Indonesia. Yogyakarta: Aswaja Pressindo.

Sopa. (2013). Sertifikasi Halal Majelis Ulama Indonesia (Studi atas Fatwa Halal MUI terhadap Produk Makanan, Obat-Obatan dan Kosmetika. Jakarta: GP Press Group.

Sudikno Mertokusumo. (1986). Mengenal Hukum (suatu pengantar). Yogyakarta: Liberty.

Syekh Muh. Yusuf Qardhawi. (1980). Halal dan Haram Dalam Islam. Surabaya: PT. Bina Ilmu.

Tempo.co. Dikutip pada laman website: nasional.tempo.co/read/news/2014/ 08/05/173597253/mui-terima-fee-label-halal dari-chicago [Diakses pada tanggal 31 Mei 2015].

Zainuddin Ali. (2011). Metode Penelitian Hukum. Ed. 1 Cet.3. Jakarta: Sinar Grafika. 